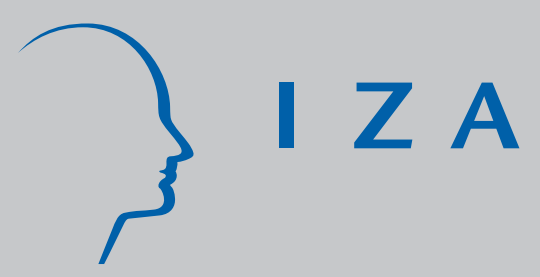

IZA DP No. 4085

Whatever Happened to the Bismarckian Welfare State?

From Labor Shedding to Employment-Friendly Reforms

Anton Hemerijck

Werner Eichhorst

March 2009 


\title{
Whatever Happened to the Bismarckian Welfare State? From Labor Shedding to Employment-Friendly Reforms
}

\author{
Anton Hemerijck \\ Free University Amsterdam \\ and Erasmus University Rotterdam
}

Werner Eichhorst

IZA

Discussion Paper No. 4085

March 2009

\author{
IZA \\ P.O. Box 7240 \\ 53072 Bonn \\ Germany \\ Phone: +49-228-3894-0 \\ Fax: +49-228-3894-180 \\ E-mail: iza@iza.org
}

\begin{abstract}
Any opinions expressed here are those of the author(s) and not those of IZA. Research published in this series may include views on policy, but the institute itself takes no institutional policy positions.

The Institute for the Study of Labor (IZA) in Bonn is a local and virtual international research center and a place of communication between science, politics and business. IZA is an independent nonprofit organization supported by Deutsche Post Foundation. The center is associated with the University of Bonn and offers a stimulating research environment through its international network, workshops and conferences, data service, project support, research visits and doctoral program. IZA engages in (i) original and internationally competitive research in all fields of labor economics, (ii) development of policy concepts, and (iii) dissemination of research results and concepts to the interested public.
\end{abstract}

IZA Discussion Papers often represent preliminary work and are circulated to encourage discussion. Citation of such a paper should account for its provisional character. A revised version may be available directly from the author. 


\section{ABSTRACT \\ Whatever Happened to the Bismarckian Welfare State? From Labor Shedding to Employment-Friendly Reforms}

The paper challenges the widespread view that Bismarckian countries with a strong role of social insurance and labor market regulation are less successful than other employment regimes and hard to reforms. This has been true about a decade ago. But both the institutional set-up and the performance of Blsmarckian countries have changed fundamentally over the last years. The paper summarizes major reform dynamics in Bismarckian welfare states which had adopted a strategy of labor shedding in the 1970s and 1980 s to combat open unemployment. As this was associated with an increasing burden of non-wage labor costs, this triggered a sequence of more employment-oriented and more fundamental reforms that eventually helped overcome a low employment situation. The paper pursues the trajectory of reforms, shows the structural change in labor market performance and points out the achievements of past reforms, but also emphasizes the need for further action in terms of education and training, activation and employment opportunities for all working age people in these countries so that flexibility and security can be reconciled.

JEL Classification: J26, J68

Keywords: Bismarckian welfare states, social insurance, social policy, employment, labor market policies

Corresponding author:

Werner Eichhorst

IZA

P.O. Box 7240

D-53072 Bonn

Germany

E-mail: eichhorst@iza.org 


\section{X.1 The adaptive capacity of the continental welfare state}

Is the welfare state fit for the $21^{\text {st }}$ century? This question has haunted European policy makers and researchers for over a decade. Sluggish growth and weak job creation around the turn of the new millennium has not only given way to a fierce ideological battle between different socio-economic 'models', triggering political strife and separating antagonistic advocacy coalitions - but also contributed to a strand of analytical literature pointing out the structural impediments to 'modernize' Continental European and Mediterranean welfare states and make them both more employment friendly and sustainable (see e.g. Scharpf and Schmidt 2000). The Bismarckian version of the European social model was pitted against a false stereotype of the 'Anglo-Saxon' model of capitalism, allegedly a 'free market without a safety net', producing high levels of poverty and inequality, but also against Scandinavian welfare states with universal benefits and strong public services in education, child-care and active labor market policies.

Rather than extrapolating policy recipes from recent economic performance, urging European OECD members to recast their social market economies along the lines of American capitalism, a more illuminating way to understand recent reform dynamics is to contextualize existing social policy repertoires and reform dynamics in the face of the changing economic and technological challenges and evolving social and demographic structures. As shown in the various chapters of this book, the striking intensity and the comprehensive character of social and economic policy reform across the majority of the socalled Bismarckian welfare regimes, including the six founding EU Member States of Germany, France, Italy and the Benelux countries, together with the later entrants Spain and Austria as well as the Visegrad countries (the Czech Republic, Slovakia, Hungary and Poland) and Switzerland, since the mid-1990s, is very much at odds with a prevalent image of a 'frozen welfare landscape' in the academic literature. Most important, the substantive extent of welfare redirection across a large number of Member States of the European Union (EU) adds up to the momentum of substantive policy change and goes far beyond the popular concepts of 'retrenchment' and 'roll-back.' But to say that the Bismarckian welfare states, as compared the Anglo-Irish and Scandinavian welfare regimes, are far from sclerotic is not to say that they are in good shape.

Today four sets of challenges confront policy makers with the imperative to redirect the welfare effort, to redesign institutions and to elaborate on new principles of social justice. From without, in the first place, international competition is challenging the redistributive scope and de-commodifying power of the national welfare state. Many academic observers believe that the increase in cross-border competition in the markets for money, goods and services has substantially reduced the room for maneuver of national welfare states (Scharpf 
1999). Economic internationalization constrains countercyclical macroeconomic management, while increased openness exposes generous welfare states to trade competition and permits capital to move to the lowest-cost producer countries. Finally, there is the danger that tax competition will result in the under-provision of public goods.

Second, from within, ageing populations, declining birth rates, changing gender roles in households as a result of the mass entry of women to the labor market, the shift from an industrial to the service economy, new technologies in the organization of work, engender sub-optimal employment levels, new inequalities and human capital-biased patterns of social exclusion. Skills-biased technological change, the feminization of the labor market, and demographic ageing, as a result of rising life expectancy and rapidly falling birth rates, are the most important drivers of the new post-industrial risk profile. While the boundaries between being 'in' and 'out' of work have been blurred by increases in atypical work, lowwages, subsidized jobs, and training programs, one job is no longer enough to keep lowincome families out of poverty. According to Gøsta Esping-Andersen et al (2002), the most important reason why the existing systems of social care have become overstretched stems from the weakening of labor markets and family households as traditional providers of welfare. In addition, new sources of immigration and segregation, especially in the housing market in metropolitan areas, pose a challenge to social cohesion. The present economic crisis is likely to pose new forms of segmentation on the labor markets to the detriment of the most vulnerable groups such as agency workers, fixed-term employees and the unemployed while labor market insiders have less to fear. Hence, risks and capacities to adapt are distributed unequally across the labor force.

And while policy makers must find new ways to manage the adverse consequences of economic internationalization and post-industrial differentiation, their endeavor to recast the welfare state is severely constrained by long standing social policy commitments in the areas of unemployment and pensions, which have ushered in a period of permanent austerity (Pierson 1998, 2001A). The maturation of welfare commitments, policies put in place to cater after the social risks associated with the post-war industrial era now seem to crowd out and overload the available policy space for effective policy responses in especially public services under conditions of low economic growth. This specter of permanent austerity is likely to intensify in the face of population ageing. Although in the current downturn many governments switch to public spending in order to reflate the economy, this may generate additional fiscal pressures in the foreseeable future.

Finally, as an intervening variable in the process, issues of work and welfare have become ever more intertwined with processes of European political and economic integration since the 1980s. It is fair to say that in the EU we have entered an era of semi-sovereign welfare states (Leibfried and Pierson 2000). European economic integration has fundamentally 
recast the boundaries of national systems of employment regulation and social protection, both by constraining autonomy for domestic policy options but also by opening opportunities for EU-led social and employment coordination and agenda setting (Ferrera 2005; Zeitlin 2005). The introduction of the internal market and the introduction of the EMU, and Stability and Growth Pact, have added a new economic supranational layer to domestic social and economic policy repertoires of individual Member States. Since the mid-1990s, the EU has taken on a far more pro-active role as a central social policy agenda setter. The European Employment Strategy, based on the new Employment Title of the Amsterdam Treaty, launched in 1997, is exemplary of the EU's new role of agenda setting policy coordination, designed to catalyze rather than steer domestic social policy reform.

Although all European welfare states face the challenges of economic internationalization, post-industrial societal change, and intensified European integration under conditions of relative macroeconomic austerity, comparative research reveals how internal and external challenges confront different clusters of welfare regimes with a distinct constellation of adjustment problems and reform agendas. It has often been argued that the institutional configuration of Continental welfare states, with their traditional Bismarckian labor market and social policy legacies, with its strong bias towards the protection of the steady employment of male breadwinners, are, in comparison to the Anglo-Saxon social model and the Scandinavians worlds of welfare, the most difficult to reform. In spite of the obvious 'irresistible forces' urging for reform, the Continental welfare model has remained an 'unmovable object' (Pierson 1998). Especially the larger political economies of France, Germany and Italy, are often mocked for their 'frozen fordism', 'inactivity traps', 'welfare without work' conundrum and 'insider-outsider' segmentation, 'perverse familialism' and 'permanent pension crises' (Palier and Martin 2007). With the Bismarckian regime type covering a large majority of EU Member States, this is all the more problematic for the EU aspiring to become - following the Lisbon agenda - the most competitive knowledge-based economy in the world.

As the series of fresh and detailed analyses of reforms implemented in Bismarckian welfare systems published in this volume show, the pace and scope of Continental welfare reform is more profound, even if incomplete, than is suggested in the literature on the 'new politics of the welfare state'. To be sure, the Continental reform momentum is very rooted in the incongruence between new economic and social contexts and institutional resilience of Bismarckian male-breadwinner social policy provisions, based on occupationally distinct, employment-related social insurance principles, underpinned by traditional (singlebreadwinner) family values (Esping-Andersen 1990; Ferrera 1998; Scharpf and Schmidt 2000; Ferrera, Hemerijck and Rhodes 2000; Palier 2006). Catching up with the more employment and family-friendly Scandinavian and Anglo-Saxon welfare state has been 
particularly difficult for Continental welfare states, as will be surveyed below. The slow but fundamental departure from 'welfare without work' strategy in Continental welfare systems since the mid-1990s is best understood as a profound transformative process of policy change across a number of intimately related policy domains. However, the reform sequence that led to ever more fundamental transformations of the Bismarckian edifice began even earlier in the 1970s with a first wave of retrenchment that eventually paved the way for more farreaching institutional and later structural reforms. Through a more or less protracted sequence of reforms, Bismarckian welfare states shifted from labor shedding to policies that aim at mobilizing labor supply as well as labor demand. Employment friendly policies replaced mainly social policy approaches to unemployment. By deliberately begging the question of Continental welfare inertia, this contribution focuses on the adaptive capacity of Europe's Bismarckian welfare states to the challenges of economic internationalization and post-industrial differentiation, and permanent austerity in the shadow of intensified European (economic) integration.

The argument is constructed as follows. First, Section 2 renders an inventory of comparative employment so as to highlight the particular weaknesses of the Bismarck-type welfare regime, together with its recent improvements, in comparison to other European welfare state families. Next, section 3 turns a diachronic qualitative analysis of the sequence and scope of employment-friendly reforms in different policy areas within and across different Bismarckian welfare systems. This overview will reveal how much the 1990s and early 2000s has been an epoch of intense policy change in the make up Europe's Bismarckian welfare states. To say that the Continental welfare state is far from sclerotic is not to say that they are in good shape. In conclusion, Section 4 highlights, by employing a life course perspective, what we think is the unfinished social reform agenda for most Continental welfare states still today.

\section{X.2 The continental employment dilemma}

Employment is the most important measure for judging the sustainability of the Continental welfare state and the success of social and economic policy reform. The reason for this is simple: benefits and social services have to be paid by the taxes and social security contributions from those in work. The more working people there are, the broader this funding base is. In the event of long-term unemployment, incapacity to work and early retirement, spending on social security goes up while at the same time revenues fall. From a sociological perspective, having a job also benefits people by giving them enhanced opportunities for self-actualization and self-esteem. Participating in the labor market is today 
the most important form of social interaction and, as such, is an indispensable element in achieving social cohesion.

The response of the Continental and Mediterranean welfare states to the process of economic restructuring in the 1970s and 1980s, but also the policy applied by the transition countries in the early 1990s was aimed at keeping open unemployment low by limiting labor supply. Most Continental welfare states began using disability pensions, early retirement, and long-term unemployment schemes to remove older and less productive workers from the labor market. Luring people out of the labor market by facilitating early retirement, increasing benefits for the long-term unemployed, lifting the obligation of job search for older workers, discouraging mothers from job search, favoring long periods of leave, easing the access to disability pensions and reducing working hours, all contributed to the characteristically Continental 'welfare without work' policy strategy that became popular in the 1980s and for most of the 1990s (Esping-Andersen, 1996). Growing demands on social security led to burgeoning costs to be borne by the labor market. From the middle of the 1980s onwards, employers in Continental welfare states increasingly began using laborsaving technology and shedding less productive employees via the social security system. This turned the Continental productivity squeeze into an inactivity trap. A vicious cycle arose of high gross wage costs, low net wages, the exit of less productive workers and rising social costs, creating a spiral of falling employment and rising economic inactivity. This also undermined the financial basis of the social security system. In addition, strict employment regulation, including minimum wages and hiring and firing restrictions, protected the insiders in key industries, while harming the participation of outsiders, youngsters, women, older workers, low skill groups and ethnic minorities (Hemerijck, van Kersbergen, and Manow 2000).

From the 1990s onwards the policy of labor supply reduction came to be brandished as a policy failure and, if continued uncorrected, as a threat to the survival of the welfare state. Towards the mid-1990s, the Continental or Bismarckian employment deficit triggered an important shift in the definition of the crisis of the Continental welfare state away from early exit adjustment strategies. Policy makers came to realize that the low level of labor market participation was the Achilles' heel of the Continental welfare state. This diagnosis initiated a series of reforms intended to overcome male-breadwinner policy provisions and to correct for past early exit policy mistakes in many areas of social and economic regulation, including collective bargaining, social security, labor market policy and regulation, pensions and social services, including health and education. To be sure, at times these reforms met with stiff resistance from the social partners, especially the trade unions, defending their privileged position in Bismarckian social insurance administration with its tradition of associational 
self-regulation by the social partners, as a corollary of the payroll financing of the Continental welfare state.

In part as a result of these reforms, since the mid-1990s, there has been a significant increase in employment across virtually all mature European welfare states over the last decade (Eichhorst and Hemerijck 2008). Figure X.1 shows the employment/population ratios among people in the working age population. What is striking is, first, the long-term increase in employment in most countries and, second, some persistent differences in the overall share of people in gainful employment across countries and families of welfare states. We can see substantial gains over the last decade, in particular in traditional low and medium employment countries. Except for three transition countries, all Bismarckian welfare states experienced job growth. It was most pronounced in the Netherlands and Spain, but also Austria, France, Belgium, Italy and Hungary saw notable increases in the employment/ population ratio so that employment rates across Europe converged to a certain extent. The Bismarckian cluster can no longer be described as a group of countries with a low employment level. In fact, Switzerland and the Netherlands join Sweden and Denmark as the group with the highest employment rates whereas Austria, the Czech Republic and Germany are above the EU-27 average and France, Belgium, Italy and Hungary approached this value considerably.

\section{Figure X.1 - Employment/population ratios 1997 and 2007}

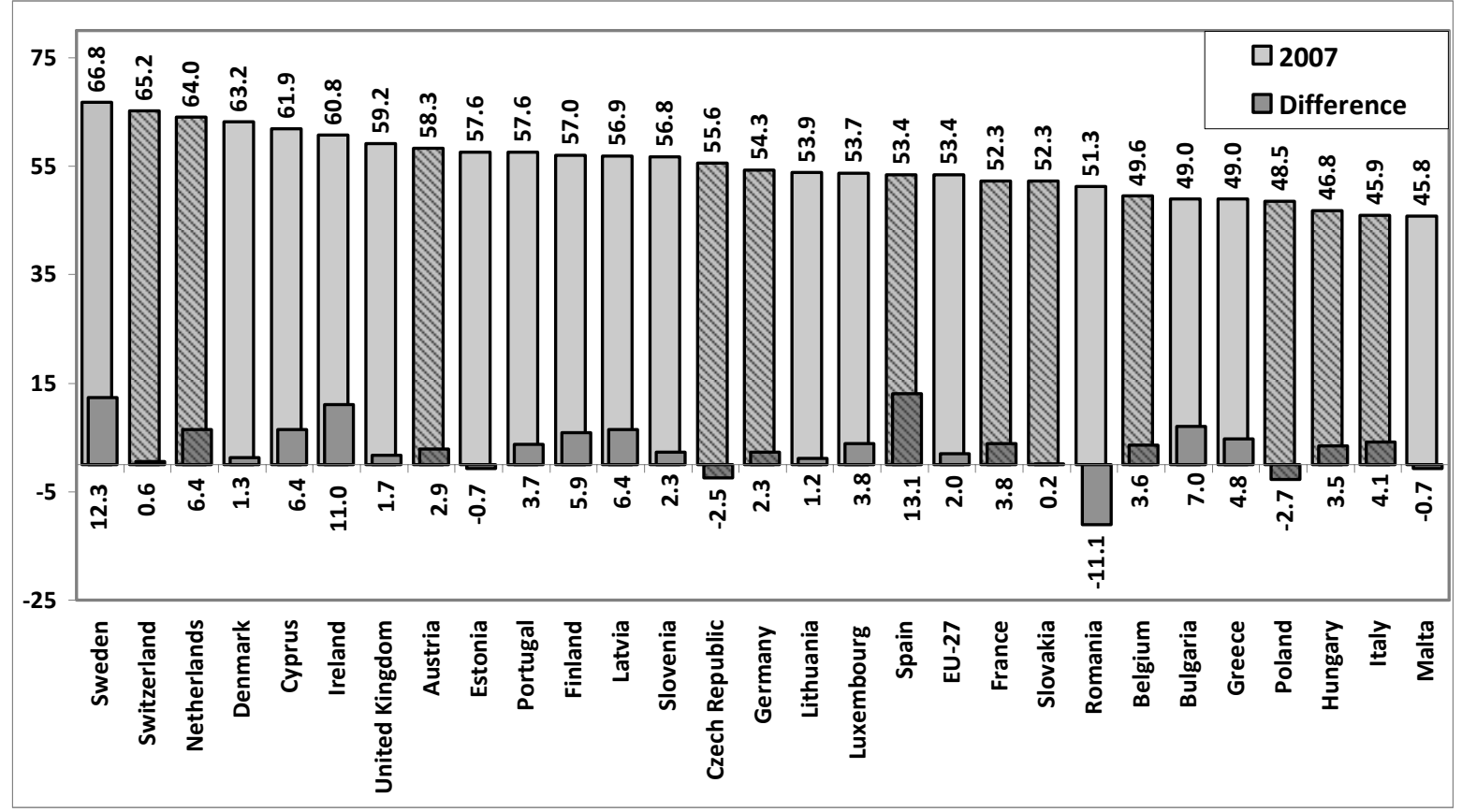

Source: Eurostat

Figure X.2 shows the long-term development of employment rates for selected European countries and the US. Unfortunately, there are no similar long-term series for the new member states. The convergence over time within the EU is striking. Now, both the Anglo- 
Saxon and the Scandinavian countries as well as Switzerland have about 75 to 80 per cent of the working-age population in employment. The same level is also achieved by the Netherlands after an impressive increase in employment over the last two decades whereas Austria almost reaches the UK employment level. The other Continental and Southern European countries are still somewhat behind with employment rates between 60 and 70 per cent. But we can see some long-term progress, in particular in Spain, Italy and Belgium while France and Germany have caught up more recently. It seems fair to say that the Bismarckian countries are now closer to the other clusters in terms of employment and have successfully overcome a low employment / low participation equilibrium.

Mirroring the improvement in employment performance, standardized unemployment rates declined in most European countries over the last decade as figure X.2 shows. Unemployment continued to decline in terms of annual data in 2008, but due to the current crisis the most recent months saw some increase in unemployment again. However, the employment performance is still much better than some years ago. What is most remarkable is the strong decline in unemployment in some Southern and Continental European countries such as Spain, France and Italy while Slovakia and Poland still suffer the highest unemployment rates in the EU. The Netherlands, Switzerland, and even Austria continue to have very low levels of unemployment. In contrast to the 1970s and 1980s, however, decreases of open unemployment are no longer associated with declines of employment and inflows into inactivity but mirror positive employment dynamics. Nevertheless, open unemployment is still the highest in some Bismarckian countries such as Slovakia, Poland, Germany, Spain and France.

Figure X.2 - Standardized unemployment rates, 1997 and 2007

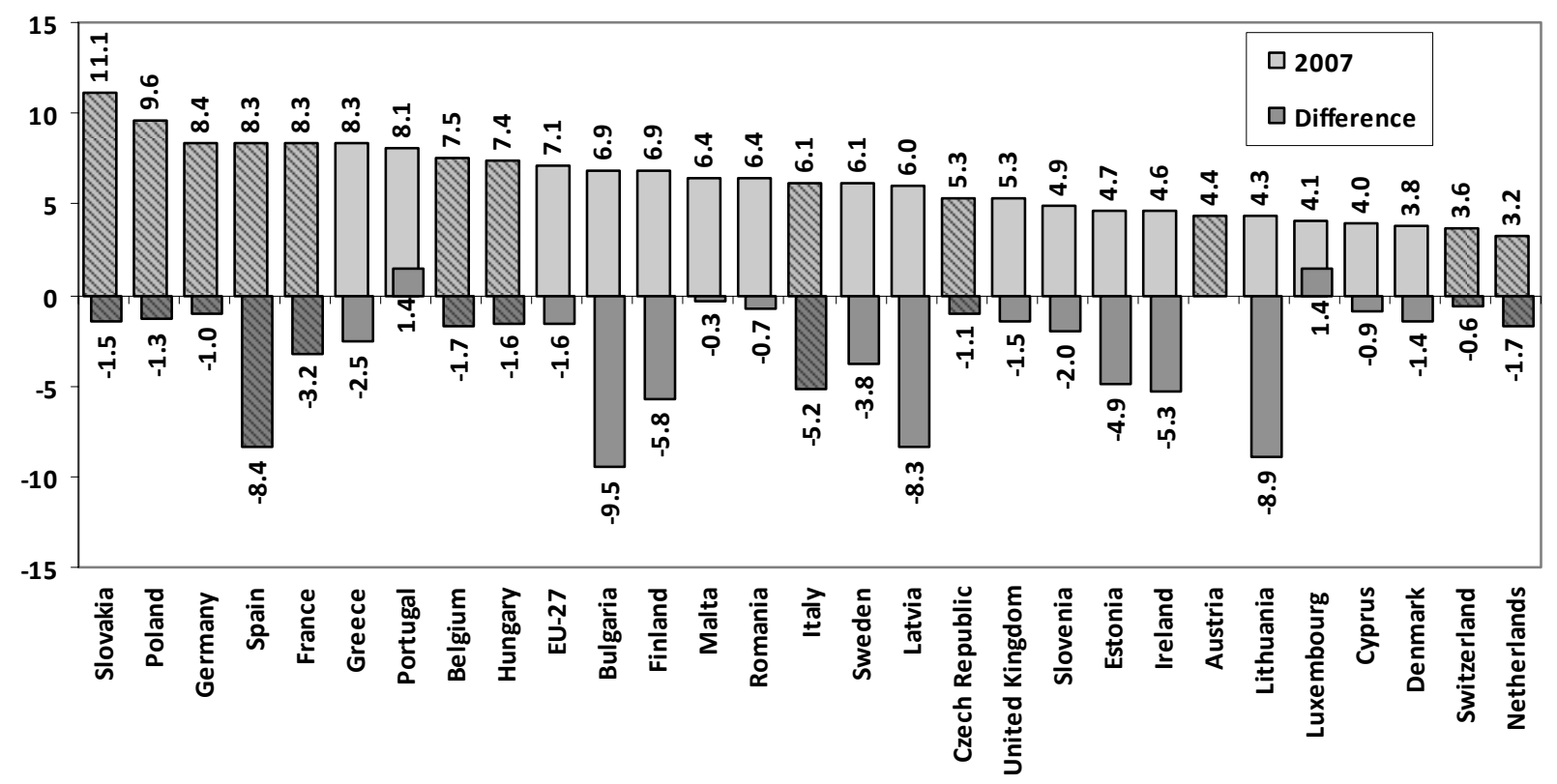

Source: Eurostat 
It was not until the second half of the 1990s that there was a limited increase in the employment rate in the Mediterranean welfare states, which, in fact, have seen some of the biggest employment gains in the EU over the last decade. The Netherlands occupies a special place comparatively because it was the first Continental welfare state with a historically low female employment rate to improve its performance, trending towards Scandinavian levels. In the age group aged 25-54 years (prime age), a strong convergence can be observed since the middle of the 1990s (figure X.3). Over the last decade we can observe substantial recovery in the Scandinavian countries after the crisis in the early 1990s, but also considerable improvement in the Continental and Southern European countries, in particular in the Dutch, Spanish and Italian cases.

Figure X.3 - Prime age employment rate, both sexes (25-54), 1997 and 2007

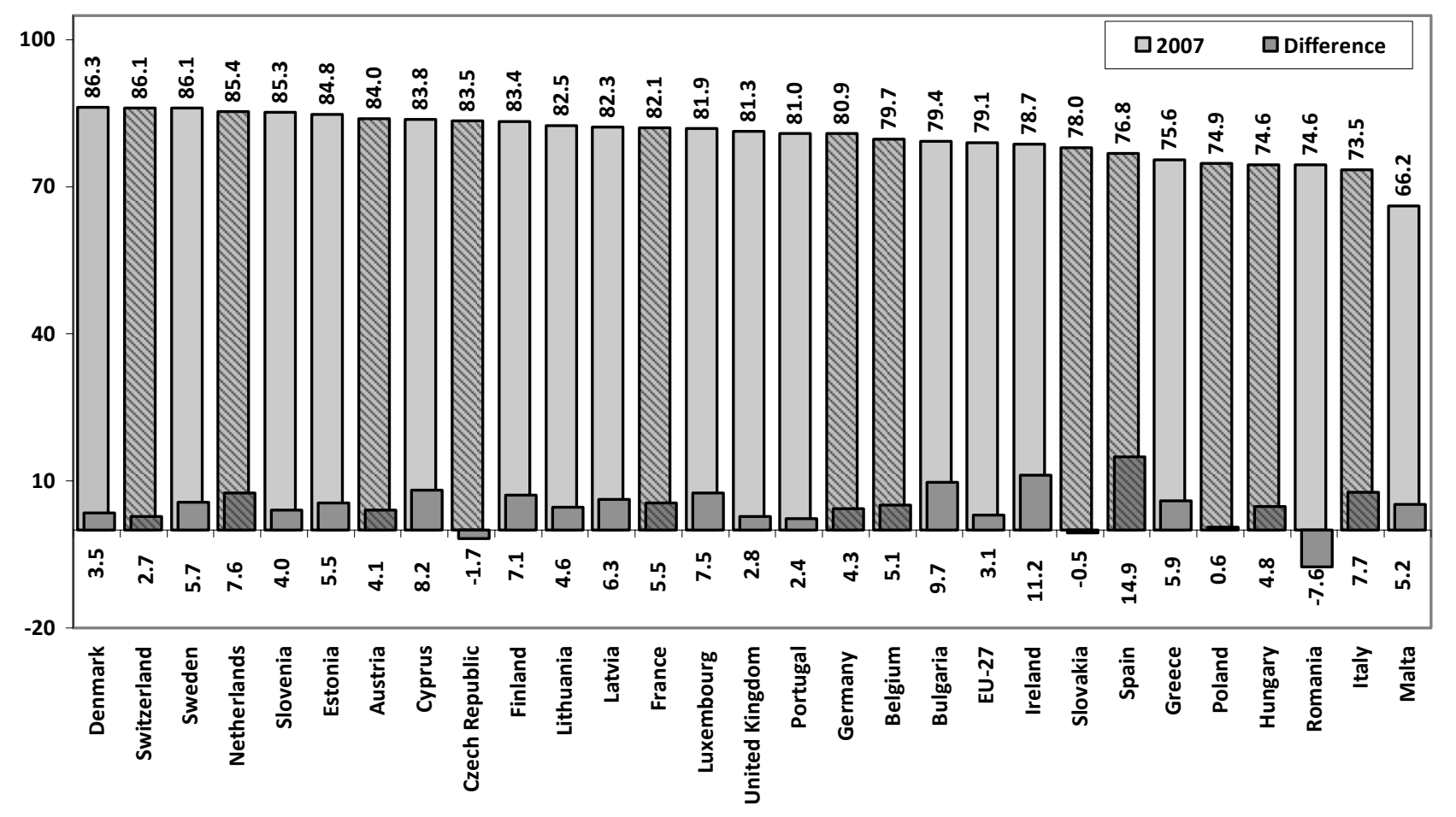

Source: Eurostat

There is much more regime-specific variation regarding the employment rates of older workers, women and the low-skilled. Differences in the extent to which these three groups are integrated into the labor market basically determine differences in the overall employment rate. With respect to the 55-64 age cohort (see figure X.4), one can clearly identify some legacy of early retirement policies in Continental and Southern welfare states, but also in the transition countries. The Continental and Mediterranean welfare states and most of the new EU member states saw a dramatic fall of more than 30 per cent in the employment rate of older workers from the 1980s due to early retirement, particularly among men. Since the end of the 1990s, the employment rate among older workers has been 
increasing strongly in Finland, but also in some Continental welfare states, with the Netherlands taking the lead. Switzerland, which did not use early retirement massively, is close to Sweden in this dimension. Other Bismarckian countries are reversing historically low employment levels of older workers. Germany and the Netherlands are now above the 50 per cent EU target employment rate for older workers while the Czech Republic and Spain are approaching this value. Austria, France, the Slovak Republic, Belgium, Italy and Hungary have also improved while Poland is lagging behind with less than 30 per cent.

Figure X.4 - Employment rates of older workers (55-64), 1997 and 2007

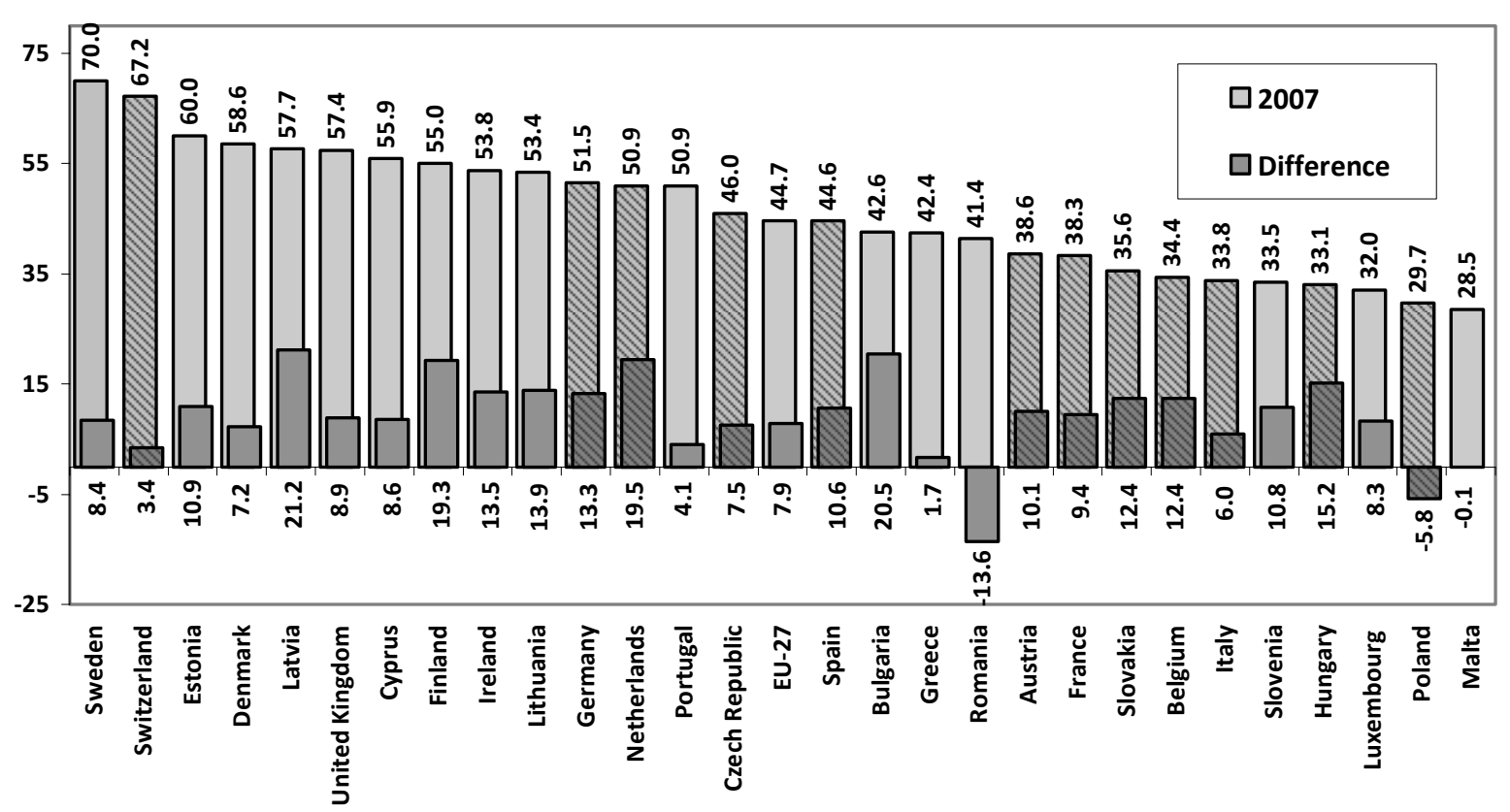

Source: Eurostat

Looking at gender, we see some cross-country convergence in the employment rate of men between 70 and 80 per cent with Switzerland and the Netherlands at the top. Male employment grew slightly in most EU countries. Again, there is a structural gap in male employment in three of the Visegrad countries and the western Bismarckian countries which relied most on early retirement (Belgium, France and Italy). 
Figure X.5: Employment rate of men, 1997 and 2007

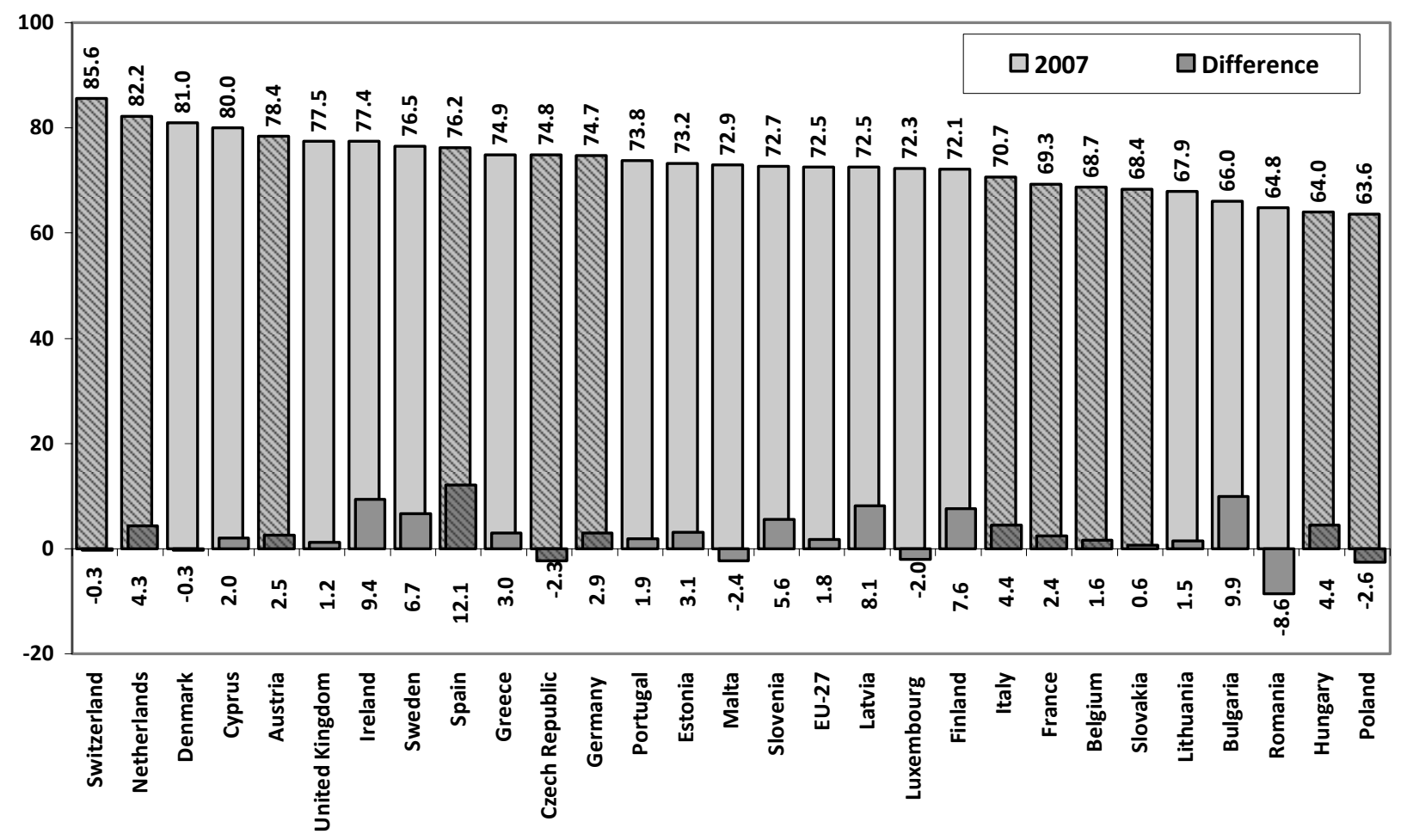

Source: Eurostat

The labor market entry of women is the most striking recent development in European welfare states (see figure X.6). In the early 1970s, the Netherlands had the lowest female employment rate in the OECD, at 29 per cent. This was lower than the figures in Ireland, Greece, Spain, and Italy, where the rates were just above 30 per cent. Since then the employment rate of women has grown strongly across all EU Member States except for some of the transformation countries. From 1997 until 2007, the rate in the Netherlands has increased by more than 12 percentage points to almost 70 per cent and even stronger in Ireland and Spain, but Germany, France, Belgium and other Bismarckian countries also experienced increases between five and nine percentage points so that female employment rates in Austria and Germany are also around 64 per cent nowadays while France reaches 60 per cent. The female employment rate in the Netherlands is currently still lower than in the Scandinavian welfare states and Switzerland, but here as elsewhere younger cohorts are undergoing a notable convergence in the direction of stronger labor force participation. For younger cohorts, female employment in Southern and Continental Europe is rapidly catching up to Northern European averages. 
Figure X.6 - Female employment, 1997 and 2007

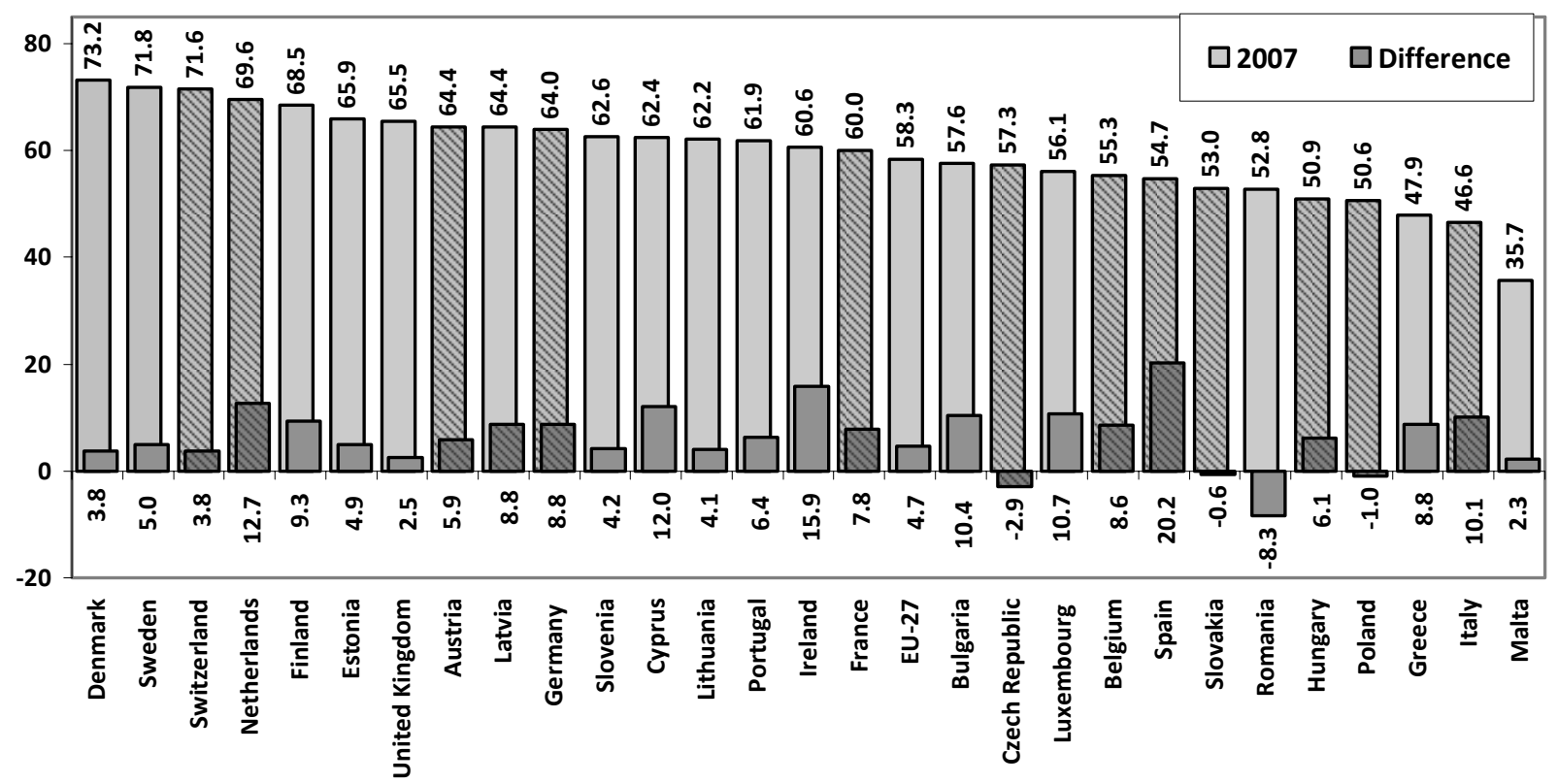

Source: Eurostat

In the Continental welfare states, the ability to work part-time has created an important means of entry to the labor market for women, in particular in the Netherlands. In countries with a long-standing tradition of female employment, such as the Scandinavian countries, part-time employment is less common. This means that the significant increases in female employment counted per heads is related to persistent, but decreasing gaps in full-time equivalent employment between the sexes as figure X.7 shows. This gap is smaller than 10 or 15 percentage points in the Scandinavian countries and some of the new EU Member States while the difference between men and women in terms of full-time equivalents is larger than 20 percentage points in Belgium, Germany and Austria and between 27 and 29 percentage points in Spain, Italy and the Netherlands. 
Figure X.7 - Gap in full-time equivalent employment rates between men and women, 2007

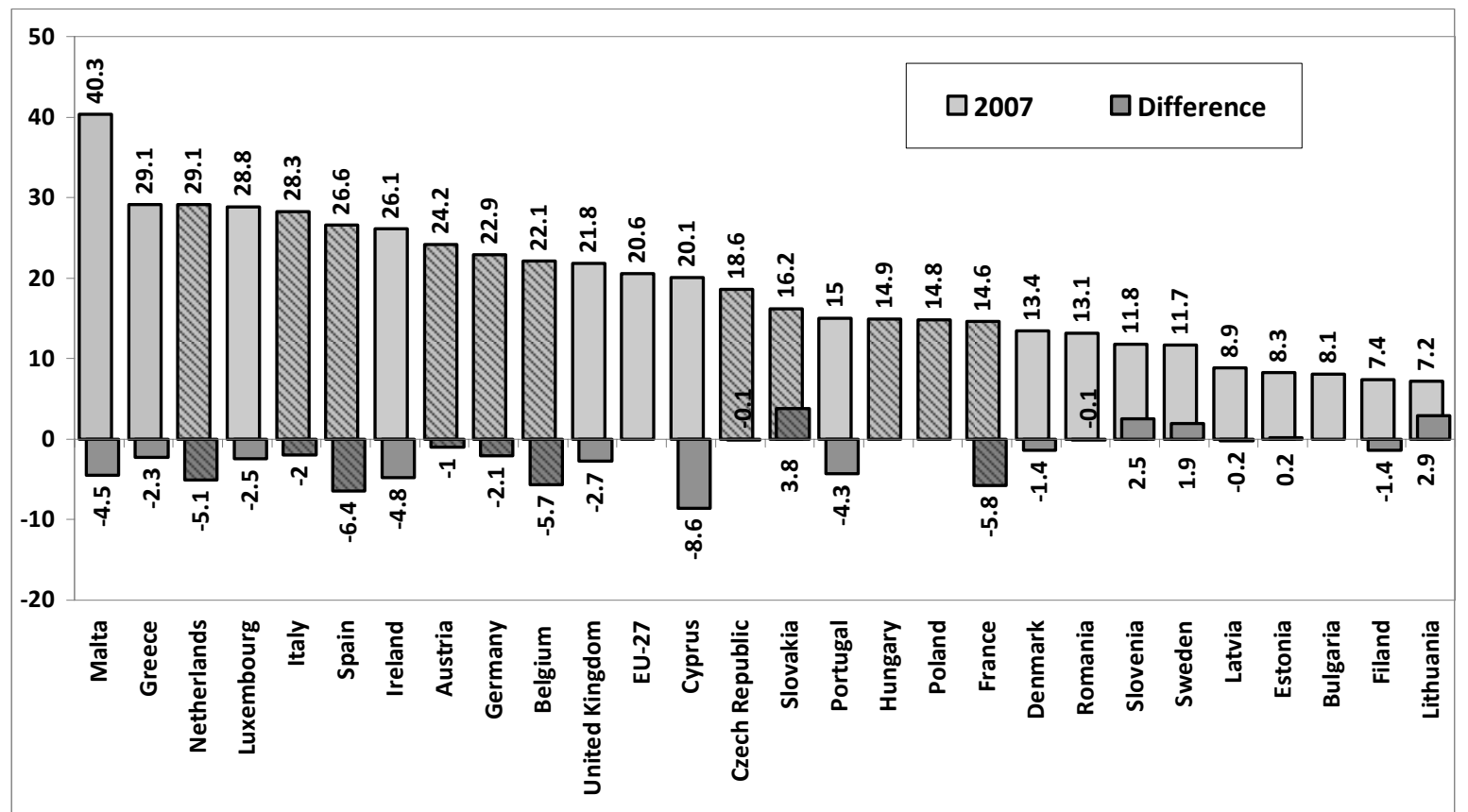

Source: Eurostat

Employment rates by skill levels differ mostly for the labor force with less than upper secondary schooling or vocational training, less so for the high skilled. Figure X.8 shows marked differences in low skill employment across countries and families of welfare states. The Netherlands, Switzerland and - notably - Spain are among the countries with the highest low-skilled employment rate. Particular deficits are found in the New Member States, but also in some Continental European countries such as France, Italy, Germany and Belgium where only about half of the low-skilled or even less are integrated into the labor market. Given the strong pressures of technological progress and globalization it is interesting to see that there is no general decline in the employment rates of the low skilled. 
Figure X.8 - Employment rates of the low skilled, 1997 and 2007

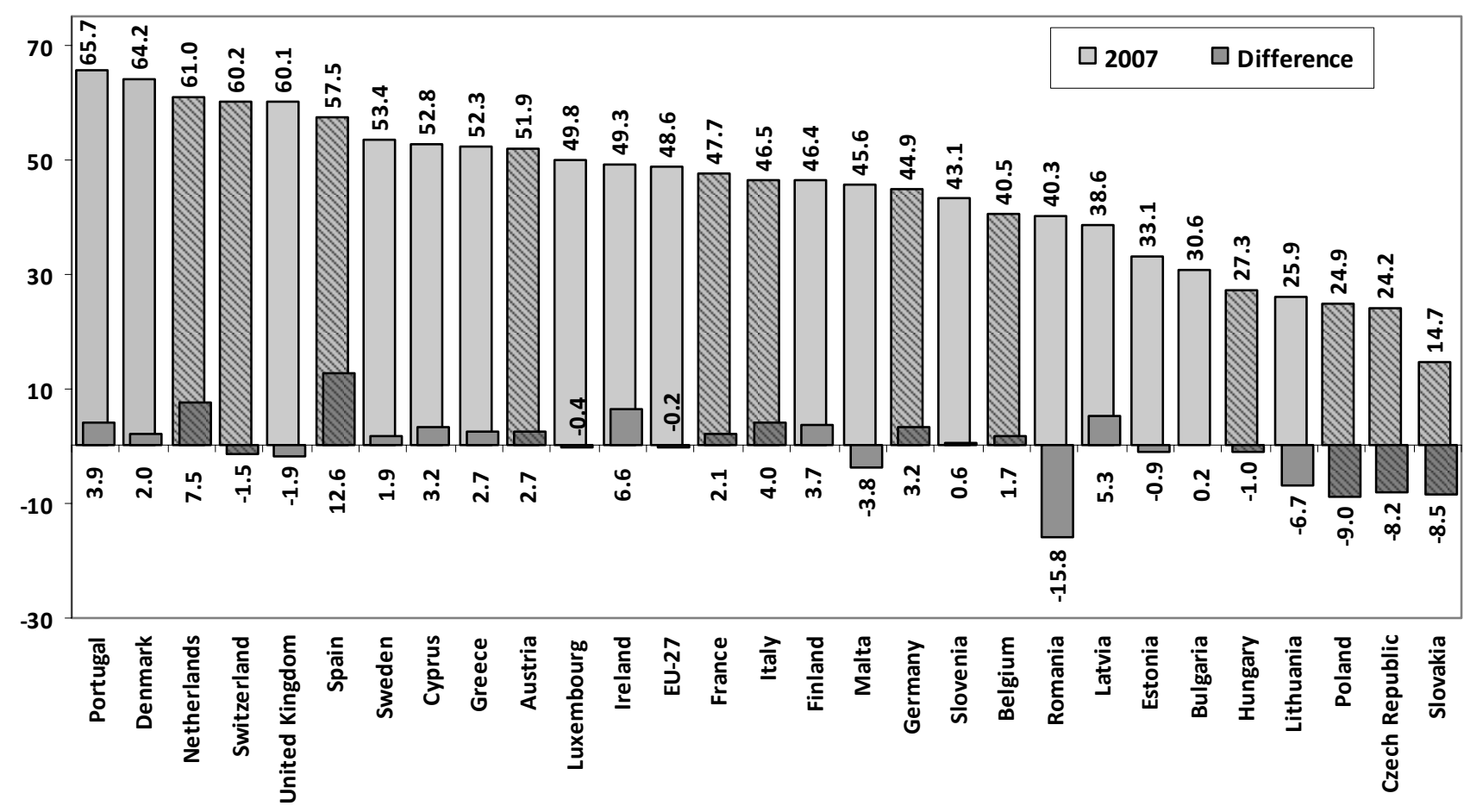

Source: Eurostat

Summarizing the overview on employment performance, we can see, first and foremost, a significant improvement in employment performance and a significant decline in unemployment across most Bismarckian welfare systems over the last ten years. However, in terms of labor market performance, the Bismarckian countries do not form a consistent cluster. While Switzerland has always had a good labor market record and is now joined by the Netherlands, the other Continental European countries as well as the Mediterranean welfare state caught up significantly although there is still some gap in comparison to the Scandinavian and the Anglo-Saxon countries with respect to most of the labor market parameters.

\section{X.3 A sequence of intense reforms}

As this book shows, Bismarckian welfare states are not what they used to be - and they are now in a fundamentally different shape than in the late 1990s when they were described as 'frozen landscapes'. The Bismarckian countries have undergone a sequence of institutional change that started in the 1970s which led to more institutional and structural changes in the following decades. Hence, the overall improvement in employment performance is related to groundbreaking social policy changes which were enacted in the majority of European 
welfare states. Since the late 1970s, consecutive changes in the world economy, European politics (most spectacularly the demise of communism in Eastern Europe), labor markets, and family structures, have disturbed the once sovereign and stable social and economic policy repertoires. As a consequence, all developed welfare states of the European Union have been recasting the basic policy mix upon which their national systems of social protection were built after 1945. Below we render a stylized sketch of the reform agendas across Bismarckian welfare states since the 1970s by policy area and country cluster. If we interpret the welfare state more broadly than social protection narrowly understood, it is possible to paint a broad, cumulatively transformative process of policy change across most the majority of Continental welfare states in a number of intimately related policy areas (Eichhorst and Hemerijck 2008).

With some stylization of national reform trajectories, we can identify four basic stages of welfare state and labor market reform in Bismarckian countries (see the introductory chapter by Palier):

1. the phase before retrenchment from the mid-1970s onwards until the late 1980s,

2. a first wave of retrenchment in the early 1990s,

3. more far-reaching institutional reforms in the second half of the nineties,

4. a second wave of more path-breaking changes in the 2000s.

Of course, not all national reform trajectories fit perfectly in the four phases, but overall the broad transformation of Bismarckian welfare states can be analyzed in terms of a stepwise and increasingly fundamental, i.e. progressive modification of established social and labor market policies.

The first phase: the good, old recipe of labor shedding

The first stage of transforming Bismarckian welfare states set in with the economic shocks of the mid-1970s. The macro-economic downturn in the aftermath of the steep increase in oil prices pushed unemployment to levels unknown in the after-war period in most European countries. To counter what was first perceived as a cyclical crisis most Bismarckian welfare states used unemployment benefits as an automatic stabilizer and implemented some Keynesian policies basically by allowing the public and the social budget to run into deficits. As part of the social approach to unemployment and to support the victims of the economic crisis most Bismarckian countries opened up exit routes from the labor market, actually in particular for workers made redundant in manufacturing which was most severely hit by adverse economic conditions. In the labor market, in the 1970s, most Bismarckian welfare states started using the social security system to remove older and less productive workers from the labor market, 
through disability pensions, early retirement, and long-term unemployment schemes. Core groups of the Bismarckian welfare state and employment model, i.e. male breadwinners in standard employment relationships, got privileged access to more generous benefits which were seen as a short-time stabilization tool in order to prevent losses in human capital first but eventually turned into pathways to long-term inactivity. Though producing short-term gains, and backed by unions as a solution to unemployment among young people, this strategy would eventually entail considerable costs in terms of job creation and fiscal pressure on the welfare state. Generous early retirement or disability benefits, but also heavy reliance on regular unemployment benefits and active labor market policy schemes, in turn, had medium-run consequences in terms of higher social insurance contributions rates for both employers and employees. But at that point in time policy makers preferred increasing contribution rates to cutting social insurance benefits although there were some marginal attempts at budgetary consolidation such as the introduction of higher user fees in health care and smaller changes in unemployment benefits. Most notably, however, in particular the Southern countries Spain (Guillén, this volume) and Italy (Jessoula and Alti, this volume) implemented some consolidation programs in pension and disability already in the 1980s ahead of other Bismarckian countries.

Overall, the welfare state arrangement itself was hardly changed in the mature Bismarckian systems where there was tendency to apply 'good old recipes.' Regarding employment, this was later seen as the root cause of the Bismarckian 'welfare without work' syndrome associated with high non-wage labor costs and a heavy reliance on non-employment benefits. In terms of welfare state change, initial responses to the crisis of the seventies can be seen as a routine relying on existing benefit schemes and labor market policies. Labor shedding indicated a regime consistent reaction to the economic shocks of the 1970s. The policy response came from within the Bismarckian regime. Outside alternatives, following the Scandinavian activation or Anglosaxon retrenchment, were not yet taken seriously. Labour supply reduction was seen as the only way to cope with rising unemployment. The regime was unchanged. To revive the Bismarckian regime, adherence to labor supply reduction made sense to the relevant policy actors.

While the mature welfare states of that period have later been described as a 'frozen' welfare states landscape, there were some notable institutional changes - not only with respect to increasing the generosity of existing benefits but also in terms of some steps to reinforce minimum income protection. This can be illustrated by the Belgian minimum income policies (see Hemerijck and Marx, this volume), but also by the introduction of the French RMI in 1988 (see Palier's chapter on France, this volume) and the more universal access to health care (see Italy, Spain and France) as well as to family benefits and the creation of mandatory unemployment insurance in Switzerland as late as in 1984 (Häusermann, this volume). These 
reforms were the first, albeit partial steps to establish a general minimum support framework which had been absent in Bismarckian welfare states thus far. Hence, in many Bismarckian countries, the phase of defensive adjustment via passive social policies was also a phase of expansion of more universal social policy coverage - in particular in those countries with less mature policy arrangements and in those areas and for those target groups typically neglected in a Bismarckian setting. This was often associated with a purification of social insurance in terms of a more direct link between contributions and benefits and a removal of redistributional elements in social insurance. This gradual shift towards tax-funded social policies gained in importance over the years to come.

While employment security for labor market insiders remained unchanged, most Bismarckian countries started liberalizing the use of more flexible jobs in the 1980s in order to allow for some additional job creation without endangering the core of the labor market. Fixedterm jobs, but also part-time employment became an increasingly prominent secondary segment in otherwise rather rigid labor markets (see the Spanish, the French or the Dutch experience). The Netherlands, however, were the first to adopt a more strategic approach to welfare state restructuring and employment creation with the renewal of corporatist negotiations in the shadow of hierarchy. In fact, the Netherlands combined wage restraint, cuts in social benefits and first steps towards activation with an expansion of flexible jobs, in particular part-time work while tolerating access to disability benefits as the Dutch exit route from the labor market (Hemerijck and Marx, this volume).

The passive labor shedding approach to unemployment led to a situation of low employment and increasing non-wage labor costs in Bismarckian welfare states.

Second phase: Cost containment and retrenchment

A first wave of more stringent retrenchment began in the 1990s in order to stabilize public budgets, limit public debts and improve international competitiveness in a situation of accelerated international and European integration. However, it was only as a result of the constraints imposed by the Maastricht criteria that, in most Bismarckian countries, a change occurred in the policies implemented: instead of increasing social contributions, governments started to try to reduce the level of social benefits. In this new context, social spending was not seen as an economic investment any more, nor as a support of economic growth, but as a cost to be better controlled. The welfare state was not seen as a purely beneficial arrangement to help the victims of economic restructuring anymore, but was increasingly perceived as a potential source of problems and disincentives. Hence, cost containment became a more important policy objective compared to the 1970s and 1980s. To consolidate the social policy budget, most Bismarckian countries increased the contributive 
character of social insurance benefits while giving a larger role to tax-funding of welfare state provisions, in particular non-contributory benefits, i.e. universal and means-tested assistance schemes, but also cross-subsidizing social insurance. The stronger differentiation between insurance and assistance also meant a clearer dualization of welfare state programs. At the same time, however, stronger minimum income elements addressed new social risks such as poverty and exclusion that resulted from insufficient access to insurance benefits. Slowly but surely mature Bismarckian welfare systems started to converge on the mixed Dutch welfare system, combining Beveridgean social assistance and minimum state pensions with more traditional vestiges of Bismarckian social insurance for core workers.

The attempt to re-establish the Bismarckian regime through labor supply reduction created tensions within the regime when long term inactivity turned out to be permanent. Not only were the labor shedding strategies ineffective in mitigating the economic economic downturn; they almost killed the Bismarckian welfare state patient. The burden of labour shedding became too great to bear in the context of the mid-1990s. The Continental model was saved, but the conditions that had sustained it before onslaught of the 1980s recession no longer existed. The persistent 'welfare without work' syndrome generated a complex reform agenda aimed at rationalizing spending by curtailing pension commitments and 'passive' benefits, improving family policy, introducing 'active' incentives into short-term cash benefits, reforming labor markets to overcome insider/ outsider cleavages, and reducing the incidence of social charges. These systems, though, are especially 'veto-heavy' and any reform must be negotiated with or around entrenched vested interests. The spur to reform in this group was the deep recession of European economies in the early 1990s, which produced a sharp rise in unemployment and ballooning public debt. From the early 1990s on, a new consensus on employment promotion spread across these countries, though the extent of reform and success in promoting new employment creation has varied.

But at the same time many Bismarckian countries continued with early retirement and disability schemes as major schemes to reduce labor supply (see the Austrian experience, Obinger and Tálos, this volume) whereas others tackled the issue of inactivity by restricting access to non-employment benefits (see the Dutch reform sequence regarding disability benefits). In the Netherlands, from 1994 onwards, the government, committed to a jobs, jobs, and more jobs' strategy, sought greater efficiencies in social security, including partial re-privatization of social risks, managed liberalization of administration, reducing social partner involvement, and introduced and intensified activation obligations for the long-term unemployed.

Some countries such as Italy were the first to start building a second pillar in pensions while consolidating the public first pillar pension regime (Amato and Dini reforms). Parallel to this, Bismarckian countries such as France or Switzerland streamlined the unemployment 
benefit system, further 'purified' the insurance schemes while strengthening assistance and minimum income protection. Activation policies were expanded and started to limit the realm of unconditional receipt of unemployment benefits more effectively. The tax share in social policy was increase to stabilize or reduce the burden of non-wage labor costs (see the CSG in France). In contrast to more ambitious reform sequences, post-unification Germany expanded its established repertoire of rising social insurance contributions to fund heavy spending on passive non-employment benefits and labor market policies to accommodate the job losses in Eastern Germany in a 'smooth' and 'social' way (Hinrichs, this volume). This, however, resulted in stronger concerns regarding the fiscal sustainability of the welfare state and international competitiveness.

In terms of the political economy, the 1990s saw a major revival of negotiated welfare state reform via social pacts (see the Netherlands, Austria, but also Spain and Italy) and stronger state intervention e.g. by introducing a parliamentary vote on the social budget (France). Reform capacities of Bismarckian welfare states were improved by a wave of successful tripartite agreements and a stronger role of governments. Social partnership also contributed to reforms narrowing the divide in labor market regulation and job protection between permanent and temporary employees after a period of strong growth in the flexible segment of the labor market (see in particular the reform sequence in Spain in the mid-nineties).

Third phase: Mobilizing the labor force

The reforms of the early nineties paved the way for institutional change beyond retrenchment. In an increasingly globalized and Europeanized economic context, welfare systems were partly seen as a cause for crisis in terms of social exclusion brought about by work disincentives and higher unemployment driven by structural weaknesses such as rigid labor market regulation and a heavy burden of taxes, and even worse, social insurance contributions. Corporatist settings were seen as somewhat detrimental to more far-reaching labor market and welfare state reforms. Building upon earlier reforms, new universal or targeted benefits beyond Bismarckian social insurance became increasingly important. The same held for the share of taxes in welfare state funding and state-driven governance as opposed to administration by the social partners. This was also associated with new modes of governance including a more prominent role of private providers of public/private partnership. This broader process of 'defrosting' spread across Bismarckian welfare states.

It is not an easy task to change policy direction, as policy actor are locked into the short term bargains of dominant policy legacies. in the short run. They needed to be convinced, often by dramatic and highly visible events, that the regime had to change. Central to the 'defrosting' of the Bismarckian welfare system was a change in the problem definition of the 
crisis of the Bismarckian welfare state in the late 1990s, away from fighting unemployment through early exit. Instead, the Scandinavian preoccupation with maximizing the rate of labour force participation became the number one priority. The commitment to high levels of employment, 'jobs, jobs, and more jobs', became to core social and economic policy objective of the Dutch governments led by Wim Kok in the 1990s.

Regarding activation, Germany, in contrast to early stages of the reform trajectory, shifted from a passive to a more active social policy by phasing out early retirement and increasing the individual's burden of proof with respect to suitable job offers, withdrawing human capital safeguard provisions as well as stabilizing non-wage labor costs by way of higher tax funding, e.g. green taxes. In many Bismarckian countries, earlier reforms towards the activation of benefit recipients and the liberalization of flexible jobs continued, but also triggered some more restrictive counter action (see France or Germany). To foster efficiency in labor market policies, public employment service monopolies were removed (e.g. in Germany or Italy) to allow for private agencies to enter this market. In reaction to the purification of contributory social insurance and the limitations to social insurance coverage, countries such as France strengthened minimal social guarantees by creating noncontributory means-tested benefits for income (RMI) and health (CMU) protection. The Netherlands probably pursued the most ambitious strategy to raise labor force participation in a low unemployment situation. This involved tackling the disability issue by tightening access to benefits, as well as using new modes of governance. In order to activate social assistance claimants a contractual approach and stronger municipal responsibility in terms of measures and resources was implemented. Performance-oriented management was also a core element of Swiss activation policies implemented after 1995. In the late 1990s, the Netherlands also managed to negotiate better employment protection for flexible jobs in exchange for some changes in dismissal protection for employees on permanent contracts (flexicurity legislation).

Fourth phase: More fundamental transformation

Given the increasingly intensive reform dynamics spreading across countries and policy areas, the fourth phase of reforms in the 2000s can be described as path-breaking change. By layering, i.e. adding non-traditional and non-Bismarckian elements to established arrangements of social and labor market policies, the overall character of the institutional edifice was modified and eventually allowed for more transformative reforms. Given European and global economic integration as well as the relevance of new social risks, 
Bismarckian countries changed their basic institutional settings and are fundamentally different from the arrangements found in the 1970s. This was not a swift and coherent change but rather the result of long and more or less protracted sequences of partial reforms. At least in some crucial situations some of the Bismarckian countries could rely on negotiated and more strategic institutional reforms while others mostly started reforming on the margins of the labor market and the welfare state so that new provisions could grow in importance and pave the way for more far-reaching reforms affecting core elements.

The 2000s were characterized by increasingly generalized activation policies and the prominent role of employment incentives and employment-friendly benefits as stronger work incentives have become a major policy orientation since the late 1990s in countries which used to pursue a social approach to unemployment. As shown by Palier (2006), the growth of minimum income protection, but also second, private pillars in pension systems, however, implies a certain dualization of social protection between social insurance and social assistance programs and between public and private regimes. Both the subsidization of private social policies and the growing importance of means-tested minimum provisions bring about a higher share of tax-funding in Bismarckian welfare states. The Bismarckian regime entered a phase of more fundamental change.

Reforms in the most recent phase were not heavily driven by the momentum of EMU but rather followed from earlier steps towards flexibility and activation. The major objective of social security now changed from passive compensation of social risks to setting individual behavioral incentives for both employers and benefit claimants to achieve labor market integration: out-of work benefits were complemented by in-work benefits, human capital safeguard clauses in activation were replaced by strict suitability criteria. Activation was dominated for some years at least by a work-first orientation, but more recently preventative social investment in human capital through early childhood education, schooling, training and lifelong learning moved up the public policy agenda (especilly in Spain, Switzerland or Germany). However, activation policies not only stressed labor market (re)integration of virtually all working-age benefit recipients but also meant a generalization of minimum income support for the population (Eichhorst and Konle-Seidl 2008). Exit routes such as disability and early retirement are being closed in those Bismarckian countries that had continued those schemes over the 1990s (see the Netherlands or Austria), whereas Belgium has been more reluctant when it comes to curtailing early retirement and activating unemployment benefits.

Activation is now a general objective implying intensified active labor market policy and new modes of governance such as target-oriented management of public agencies, which have become more autonomous from social partner influence over time, and contractual relationships between the state and the individual as well as between government and private 
providers (see e.g. in the Netherlands, Switzerland or Austria). This, in fact, is associated with a dual social protection model, combining Bismarckian social insurance, which is still in place for core workers, with Beveridgean minimum income protection systems. Both Belgium and France also targeted stricter activation at recipients of minimum income support and implemented stronger in-work benefits for low-wage earners (e.g. the French 'prime pour l'emploi') or their employers via exemptions from social insurance contributions. With the 2005 Hartz IV reform, Germany implemented a similar general assistance scheme for all working-age inactives who were capable of working by merging former unemployment assistance and social assistance. This was complemented with tight suitability criteria and sanctioning provisions so that strong activation requirements concerned all long-term unemployed. Germany shifted from a passive welfare state accommodating economic restructuring through long-term benefit receipt to one of the most ambitious and universal activation regimes. However, most countries aim at a more unified mode of governance and administrative streamlining of benefit payments, activation and service provision for all jobseekers, in particular the long-term unemployed. This leads to new cooperation arrangements or mergers between municipal welfare offices, public employment services and/or unemployment insurance (see the German ARGE for long-term unemployed or the most recent French 'pôle emploi' bringing together unemployment insurance and public labor market policies).

Parallel to further benefit recalibration in public pension schemes and the introduction of minimum pension provisions, a new wave of pension reforms introduced or strengthened employer-based supplementary pensions and the fully-funded, private, but subsidized pillar of old-age pension, e.g. the Riester reform in Germany or PERP and PERCO in France. A similar objective lies behind the new severance pay funds in Austria ('Abfertigung neu'). Finally, the growing role of flexible employment paved the way to further flexicurity legislation in highly regulated labor markets such as Spain while in other countries such as Germany temporary work agencies, self-employment, and also part-time jobs provide for alternative flexibility channels so that dismissal protection is less under pressure than a decade ago. The Visegrad countries, which had implemented passive social policies to cope with the transition crisis in the 1990s - similar to what the other Bismarckian countries had done in the 1970s and 1980s - embarked on the trend towards retrenchment, recalibration and activation in the current decade (Cerami, this volume).

\section{X.4 An unfinished social reform agenda for Bismarckian countries}

Neither the doomsday scenario of the demise of the Bismarckian welfare state, predicted by mainstream economists in the early 1990s, nor the prevailing image of a frozen welfare 
status quo' can be corroborated by the welfare reform experience highlighted above. Over the past two decades, as the above inventory of reforms shows, many European welfare states have - with varying degrees of success - taken measures in order to redirect economic and social restructuring by pushing through adjustments in macro-economic policy, industrial relations, taxation, social security, labor market policy, employment protection legislation, pensions and social services, and welfare financing. The result has been a highly dynamic process of self-transformation of the Bismarckian welfare family (Hemerijck 2002), marked not by half-hearted retrenchment efforts but by more comprehensive trajectories of 'recalibration', ranging from redesigning welfare programs to the elaboration of new principles of social justice (Ferrera, Hemerijck and Rhodes 2000; Ferrera and Hemerijck 2003; Pierson 2001b). It is no exaggeration to say that Continental welfare states are in the midst of a general paradigmatic shift away from systems geared to income and status maintenance towards more universal, but activating and employment-friendly as well as gender-neutral welfare systems. Many reforms were unpopular, but a fair amount occurred with the consent of opposition parties, trade unions, and employer organizations. A core feature, however, is the sequential character of reforms. More far-reaching institutional changes were facilitated by early reforms, initially often of minor character or at the margins of the labor market or the welfare state, but later to be generalized as a consequence of institutional layering (Palier, 2005, Bonoli, Palier, 2007).

What stands out in the Bismarckian reform momentum of recent times is the redefinition of the employment problem away from managing unemployment toward the promotion of employment, on the basis of activation, active ageing/avoidance of early retirement, parttime work, lifelong learning, parental leave, gender mainstreaming, flexicurity, balancing flexibility with security, and reconciling work and family life. Moreover, Bismarckian welfare states are in the process of moving away from the breadwinner/ caregiver model, under which mothers are expected to stay home with children, to a model of 'employment for all', under which mothers are expected to enter the labor force. This transition, which Ann Orloff captures in terms of the 'farewell to maternalism', is not merely the product changing gender values (normative recalibration), it is also part of a more deliberate strategy of policy makers to attract mothers in the face of population ageing into the work force through activation programs, tax subsidies, part-time employment regulation, and the expansion of family services (Orloff 2006).

The task of employment and social policy systems should, first and foremost, be to support the development of each person, with measures tailored to people's capabilities and needs, and thus enabling them to reach their full potential. Many of the so-called 'new social risks', like family formation, divorce, the elderly becoming dependent on care, declining fertility, and accelerating population ageing bear primarily on young people and young families, 
signifying a shift in social risks from the elderly to the young. New risk bearers however lack critical social and political influence. Their ability to exert electoral and extra-parliamentary pressure is limited by the fact that, for most people, exposure to new social risks is a transitory phase of the family life course, concerned with child rearing, elder care, or labor markets entry and exit (Bonoli, 2005). Since family and gender issues have remained subsidiary in the reform momentum of the past two decades, post-industrial social and economic change seems perversely to reinforce an over-accumulation of insurance benefits on the side of 'guaranteed' breadwinner workers with quasi-tenured jobs, alongside inadequate protection for those employed in the weaker sectors of the labor market, particularly youngsters, women, immigrants and older low skilled workers. Late entry into the labor market of youngster, early exit of older workers, together with higher life expectancy confronts the welfare state with a looming financing deficit. The majority of Europe's mature Bismarckian welfare states are confronted with the distributive syndrome of labor market segmentation between 'insiders' and 'outsiders' in terms of both dualized social protection system (insurance vs. assistance) and forms of employment, i.e. standard vs. 'atypical' jobs.

Welfare reform in Bismarckian systems is, as we have exemplified above, extremely difficult, but surely not entirely inconceivable. Path-breaking reforms, such as the Dutch reforms of the 1990s and Hartz reforms in Germany, brought policy reformers to expose the drawbacks of the widely popular welfare status quo, together with the old objectives, purpose and principles standing social policies were based on. By framing reform resistance as problematic, policy reformers offended entrenched policy stakeholders and organized interests in all Bismarckian states. This necessarily implied that reform oriented policy makers have had to make consistent attempts to legitimize new policies and their underlying (new) normative principles. Communicating will power to reform, while propagating fair solutions, has proved to be imperative to changing prevailing policy repertoires. In the Bismarckian institutional context, there is an inherent tension here between, on the one hand, exposing stakeholders abuse of their vested interest positions, and, on the other hand, to appeal to stakeholders to rethink reform resistance in order to forge a more productive political and societal consensus. However, structural change in Bismarckian countries also means a recalibration of the relationship between government, employers and trade unions some of the most important reforms were implemented by the social partners in the government's 'shadow of hierarchy' (Scharpf 1997) or brought about a structural weakening of social partnership in some countries, e.g. Germany or France, whereas in others such as the Netherlands, Switzerland or Austria, tripartite dialogue was revived and proved capable of adjusting to a new economic and societal environment. Moreover, strong and operative 
social partnership seems to be associated with less severe dualization of labor markets and smoother adjustment.

In recent years, the normative focus of social policy hereby shifts from ex post social insurance compensation towards preventive or ex ante employability, hinging on the deployment of resources to improve and equalize citizens' individual abilities to compete in the knowledge economy. In order to connect social policy more fully with a more dynamic economy and society, citizens have to be endowed with capabilities, through active policies that intervene early in the life cycle rather than later with more expensive passive and reactive policies (Esping-Andersen et al. 2002). At the heart of the new narrative lies a reorientation in social citizenship, away from freedom from want towards freedom to act, prioritizing high levels of employment for both men and women as the key policy objective, while combining elements of flexibility and security, under the proviso of accommodating work and family life and a guaranteed rich social minimum serving citizens to pursue fuller and more satisfying lives (Diamond 2006). In the shadow of intensified economic internationalization and post-industrial societal change, a relative shift from the social protection function of the welfare state to more of an emphasis on the social promotion function of the welfare state seems imperative. The differences in the allocation of public resources to either investment policies (such as education and training) or to compensating policies such as social benefits and passive and active labor market policies are most evident in figure X.10 which shows how public spending on education and social expenditure in per cent of GPD combined in 2005. While the overall association between both areas of public spending is positive in the Scandinavian ones, also some Bismarckian countries like Belgium and France now combine above-average spending on social policies with above-average spending on education. Germany and Italy, in contrast, spend a lot on social purposes but are relatively stingy on educational expenditure. 
Figure X.9: Public social expenditure and spending on education in per cent of GDP, 2005

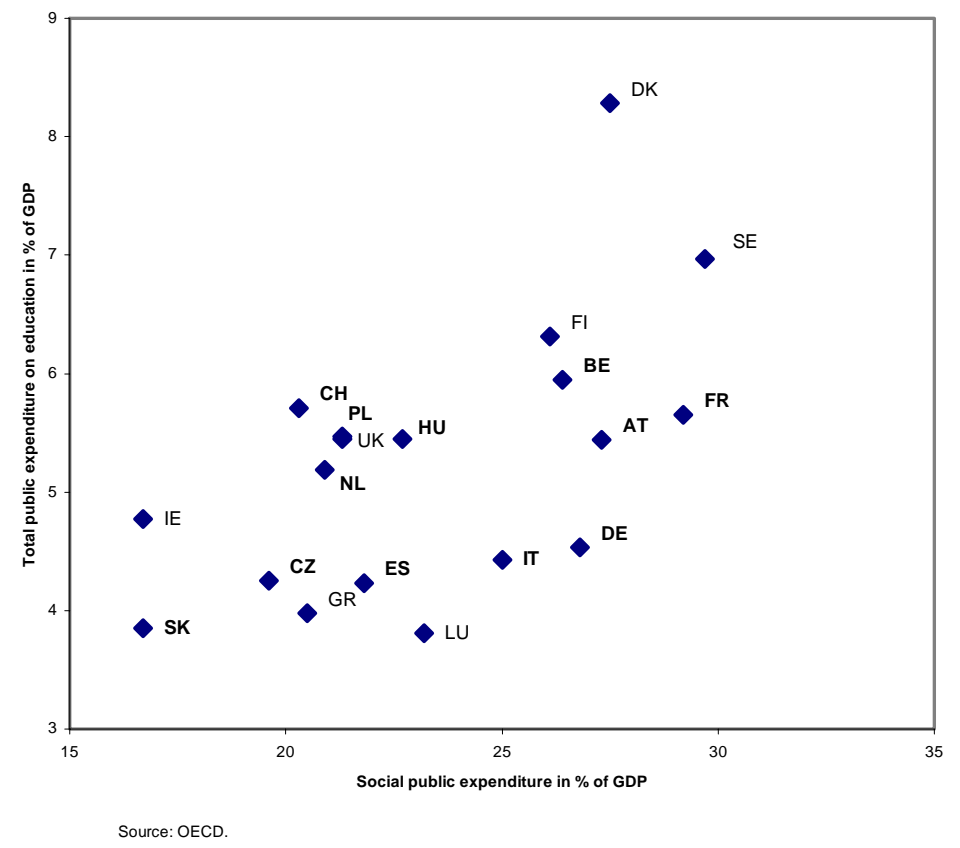

Source: OECD

Following several years of sound economic growth and strong employment expansion, European welfare states now face a dramatic economic downturn, for the first time since the launch of the Lisbon strategy in 2000. A major stress test for the Continental welfare state lies ahead. As the financial crisis deepens and spills over into rising unemployment and social duress, the need for resilient employment and social policy is greater than ever. This precarious juncture creates a number of policy temptations. There is the obvious temptation of completely abandoning fiscal discipline to save jobs and maintain, as much as possible, the welfare status quo. Then there is the short sighted seduction of retrenching current welfare commitments to foster financial and budgetary stability. Equally ineffective is the still alluring strategy to fight unemployment through reducing labour supply through early retirement, for which all Bismarckian welfare system fell in the 1980s and 1980s. Worse still is the nationalist and protectionist temptation that proved so disastrous in the 1930s. There is a real danger of adopting incoherent policy combinations that may actually deepen the economic downturn, worsening job losses, reducing state revenue, eroding pensions, and widening the gap between rich and poor. Historical mistakes, like deflationary contraction of the 1930s, and labour supply reduction of the 1980s and 1990s, should surely be avoided. In these uncertain times, we must not lose sight of the overall aim of creating employmentfriendly, fair and efficient, welfare systems. Short- to medium-term macroeconomic measures are necessary to respond to immediate needs, but such measures should be 
consistent with the ongoing recalibration efforts to prepare domestic welfare state and EU social policy for the challenges of the $21^{\text {st }}$ century. There are seven policy priorities at stake:

\section{Let automatic stabilizers work}

So as to prevent a global economic abyss, it is necessary to let automatic stabilizers work, to protect citizens from the harshest effects of rising unemployment, while at the same time serving to safeguard economic demand. In the longer run, confidence in the economy relies on sound public finances. Today we can observe, in sharp contrast to the Great Depression, how a fierce anti-deflationary macroeconomic policy response has rapidly come to fruition in the OECD area. There is clear policy consensus that a Keynesian crisis should be met by an expansionary policy of anti-cyclical macroeconomic management across Europe. This kind of European policy coherence was surely lacking in the 1970s and 80s era of stagflation. Also the stability of the euro should not be underestimated, in that a common currency forestalls any policy of competitive devaluation. The internal market, enhanced in scope and strength by the addition to the EU of ten new members states from Central and Eastern Europe, surely puts a break on excessive protectionism. Last but not least, under the current financial crisis, it should not be forgotten that with social protection outlays averaging $28 \%$ of GDP in the EU, European social policies already act as important anti-cyclical automatic stabilizers. Rules and regulations in public finances, like the Stability and Growth Pact, define all government expenditures as consumption. Many of the policy proposal listed below concern social investments with a reasonable rate of long term return for economy and society. We have to find a way to prioritize social investments without undermining the principles of sound public financing. Take social investments out of SGP rules could be a step in the right direction.

Strengthen long-term attachment to the labor market

The overriding policy lesson in our advanced economies is that in the face demographic ageing and in the light of a declining work force, nobody can be left inactive (for long). Impending redundancies should be mitigated by temporary and short term unemployment benefits, combined with additional training measures. Any kind of job, be it short term, parttime or subsidized, is better than no job at all to forestall unemployment hysteresis and deskilling. With ageing labour markets will be tight in the long run. The interaction between economic performance and the welfare state is largely mediated through the labor market. The majority of Europe's Bismarck-type welfare states are confronted with a syndrome of labor market segmentation between 'insiders' and 'outsiders' (Schmid 2008). Relaxed hiring and firing legislation is best combined with generous social protection and active training and labour market policies to maximize employment. The ability to balance careers and family- 
life is also crucial for removing gender biases in the labour market. While there is strong social security on the side of 'guaranteed' breadwinner workers with quasi-tenured jobs, most Bismarckian welfare states continue to provide only inadequate protection for vulnerable groups such as young labor market entrants, women, immigrants and older low skilled workers. Most likely, labor markets will become ever more flexible. While the boundaries between being 'in' and 'out' of work have been blurred by increases in atypical work, lowwages, subsidized jobs, and training programs, one job is no longer enough to keep lowincome families out of poverty. Post-industrial job growth is highly biased in favor of high skill jobs. However, increased labor market flexibility, together with the continuous rise in female employment will, in addition, also encourage the growth of a sizeable amount of low skill and semi-skilled jobs in the social sector and in personal services. The Bismarckian policy challenge is how to mitigate the emergence of new forms of labor market segmentation through what could be called 'preventive employability', combining increases in flexibility in labor relations by way of relaxing dismissal protection, while generating a higher level of security for employees in flexible jobs. Flexible working conditions are often part and parcel of family friendly employment policy provisions. There is a clear relation between the ratio of part-time jobs and female employment growth. But the ability of part-time employment to harmonize careers with family depends very much on employment regulation, whether parttime work is recognized as a regular job with basic social insurance participation, and whether it offers possibilities for career mobility.

Active family investment strategy

The revolution in women's role remains incomplete, raising new welfare problems, that need to be addressed. Depressed female participation widens the gender gap and constrains economic growth. Moreover, also fertility hinges on effective gender equality. Generous parental leave, employment security, and, especially, high quality child care, in turn, positively affects long term productivity through higher fertility, higher female earnings, more tax revenue, and better skills on the part of future generations, thus significantly mitigating the adverse effects of population ageing. The Bismarckian welfare state still have to adjust to the feminization of post-industrial labour markets. As inequalities widen, parents' ability to invest in their children's success is also becoming more unequal. Since life chances are so strongly determined by what happens in childhood, a comprehensive child investment strategy is imperative. Inaccessible childcare will provoke low fertility, low quality care is harmful to children, and low female employment raises child poverty. Increasing opportunities for women to be gainfully employed is a key step. But the concept of early childhood development needs to go beyond the idea that childcare is necessary to allow 
parents to reconcile work and family life. Early childhood development is imperative to ensure that children will be life-long learners and meaningful contributors to their societies.

Lifelong human capital investment push

In the new, knowledge-based economies, there is an urgent need to invest in human capital throughout the life of the individual. Youth with poor skills or inadequate schooling today will become tomorrow's precarious worker. Considering the looming demographic imbalances in Europe, we cannot afford large skill deficits and high school dropout rates, especially in the Southern Continental welfare states (above 30 per cent in Spain, almost 25 per cent in the Netherlands and less than 15 per cent in Denmark or Sweden). Strong social inheritance is not affordable in the long run. The architecture of education systems makes a real difference. High inequality and high educational differentiation reinforce cognitive poverty, early stratification, and social segregation. Social and employment policies that are aimed at increasing skills and developing the quality of human resources act as 'productive factors' in our economies. The revitalization of both the Irish and the Finnish economy is in part based on increased investments in education, preventing early departure from formal education and training, and facilitating the transition from school to work, in particular school leavers with low qualifications. Here the majority of Bismarckian welfare states continues to lag behind significantly.

Later and flexible retirement

As life expectancy increases and health indices improve, it will be necessary to keep older workers in the market for longer. Sustainable pensions will be difficult to achieve unless we increase employment rates of older workers and raise the retirement age to at least 67 years. Two trends justify an adjustment in our thinking about retirement: a) the health status of each elderly cohort is better than that of the last; at present a man aged 65 can look forward to a further 10 healthy years. And, b) the gap between old age and education is rapidly narrowing, so that old people in the future will be much better placed than now to adapt in the coming decades with the aid of retraining and lifelong learning. The education gap between the old and the young will begin to disappear when the baby-boomers approach retirement. Beyond the development of multi-pillar, including both PAYGO (pay-as-you-go) and funded schemes, in the area of pension policy, the challenge lies in how to allocate the additional expenditures that inevitably accompany population ageing (Myles 2002). Of crucial importance remains a general, revenue financed, first tier pension guarantee with a price index guarantee for the next generation of flexible labor market cohorts. Sustainable pensions will be difficult to achieve unless we raise employment rates of older workers and raise the retirement age to at least 67 years. Delaying retirement is both effective and 
equitable. It is efficient because it operates simultaneously on the nominator and denominator: more revenue intake and less spending at the same time. It is intergenerationally equitable because retirees and workers both sacrifice in equal proportions. We are all getting healthier and more educated with each age cohort. Flexible retirement and the introduction of incentives to postpone retirement could greatly alleviate the pension burden. Although there has been a slight increase of part-time work among the elderly, it has been shown that part-time work and participation rates among older people are positively related; there is still little systematic and comprehensive policy activity to enhance the variable opportunity set for older workers. If older workers remain employed ten years longer than is now typically the norm, household incomes will increase substantially. This means less poverty and need for social assistance and greater tax revenue.

Migration and integration through participation

Priority should be given to problems of participation and integration of migrant groups, whose rates of unemployment in the EU are, on average, twice that of nationals. Integration and immigration policy should have a central place in our discussion about the future of the Continental welfare state, something we failed to do in the past. In Europe's ethnically and culturally diverse societies, the welfare state faces a major challenge in ensuring that immigrants and their children do not fall behind. Economic exclusion and physical concentration (ghettoization) reinforces educational underperformance, excessive segregation and self-destructive spirals of marginalization.

\section{Minimum income support}

We cannot assume that the measures described above will remedy current and future welfare deficiencies. Hence, it is impossible to avoid some form of passive minimum income support. An unchecked rise in income inequality would worsen citizens' life chances and opportunities, result in lost productivity and more passive income support costs. It is, therefore, necessary to have an even more tightly woven net below the welfare net for the truly needy to meet minimum standards of self-reliance. The key lesson of the Great Depression of the 1930s eventually ushered in Keynesian demand-side policies and, after a devastating World War, firmly established the need for some sort of safety net in every major industrial democracy. This lesson to match social promotion with social protection continues to stand tall. 


\section{References}

Bonoli, G. (2005). "The politics of the new social policies. Providing coverage against new social risks in mature welfare states", Policy and Politics, 33(3), pp 431-449.

Bonoli G. and B. Palier B (2007). "When Past Reforms Open New Opportunities: Comparing Old Age Insurance Reforms in Bismarckian Welfare Systems", Social Policy and Administration (2007) 41:555- 573.

Daly, M. (2000). “A Fine Balance: Women's Labour Market Participation in International Comparison." In F.W. Scharpf and V.A. Schmidt (Eds.), Welfare and Work in the Open Economy. Volume II. Diverse Responses to Common Challenges. Oxford: Oxford University Press.

Diamond, P. (2006). "Social J ustice Reinterpreted: New Frontiers for the European Welfare State." In A. Giddens, P. Diamond and R. Liddle (Eds.), Global Europe, Social Europe. Cambridge: Polity Press.

Eichhorst, W., M. Grienberger-Zingerle and R. Konle-Seidl (2009). Activation Policies in Germany: From Status Protection to Basic Income Support, forthcoming in: German Policy Studies 2009;

Eichhorst, W. and Hemerijck, A. (2008). “Welfare and Employment: A European Dilemma.” IZA Discussion Paper 3870.

Eichhorst, W. and R. Konle-Seidl (2008). “Does Activation Work?” In W. Eichhorst, O. Kaufmann and R. Konle-Seidl (Eds.), Bringing theJ obless into Work? Berlin: Springer.

Esping-Andersen, G. (1990). The Three Worlds of Welfare Capitalism. Cambridge: Polity Press.

Esping-Andersen, G. (1996), 'Welfare States without Work: the Impasse of Labour Shedding and Familialism in Continental European Social Policy', in: G. Esping-Andersen (ed.), Welfare States in Transition; National Adaptations in Global Economies. London: Sage;

Esping-Andersen, G., Gallie, D., Hemerijck, A., and J. Myles (2002). Why We Need a New Welfare State. Oxford: Oxford University Press.

Ferrera, M. (2005). The Boundaries of Welfare: European Integration and the New Spatial Politics of Solidarity. Oxford: Oxford University Press.

Ferrera, M. and Hemerijck, A. (2003). “Recalibrating Europe's welfare regimes.” In J . Zeitlin D.M. Trubek (Eds.), Governing Work and Welfare in the New Economy. European and American Experiments. Oxford: Oxford University Press.

Ferrera, M., Hemerijck, A. and Rhodes, M. (2000). The Future of Social Europe: Recasting Work and Welfare in the New Economy. Oeiras: Celta Editora.

Hemerijck, A. (2002). "The self- transformation of the European social model(s)." In G. EspingAndersen, D. Gallie, A. Hemerijck and J. Myles (2002), Why we Need a New Welfare State. Oxford: Oxford University Press.

Hemerijck, A., van Kersbergen, K. and Manow, P. (2000) 'Welfare without work? Divergent experiences of reform in Germany and the Netherlands'in: S. Kuhnle (ed.), Survival of the European Welfare State, Routledge - Taylor \& Francis Group, London 2000, pp.106-127

J enson, J . (2006). “The European Social Model: Gender and Generational Equality.” In A. Giddens, P. Diamond and R. Liddle (Eds.). Global Europe, Social Europe. Cambridge: Polity Press.

Leibfried, S. \& P. Pierson (2000) 'Social policy: left to courts and markets?' pp. 267-292 in H. Wallace \& W. Wallace (ed.) Policy-making in the European Union, 4th edition, Oxford: Oxford University Press. 
Myles, J. (2002). "A new social contract for the elderly." In G. Esping-Andersen, D. Gallie, A. Hemerijck and J . Myles (2002), Why we Need a New Welfare State. Oxford: Oxford University Press.

Orloff, A.S. (2006). “Farewell to Maternalism.” In J .D. Levy (Ed.), The State After Statism. Cambridge, MA: Harvard University Press.

Palier, B. (2005). "Ambiguous Agreements, Cumulative Change: French Social Policy in the 1990s" In W. Streeck and K. Thelen (Eds.), Beyond Continuity. Institutional Change in Advanced Political Economies. New York: Oxford University Press. 127- 144.

Palier, B. (2006), "The Politics of Welfare reforms in Bismarckian Welfare Systems"; Revue Française des Affaires Sociales, vol.1, pp 47-72.

Palier, B. and Martin, C. (2007). “Editorial introduction. From a 'Frozen Landscape' to Structural Reforms: the Sequential Transformation of Bismarckian Welfare Systems." Social Policy and Administration 41(6), 535-554.

Pierson, P. (1998). "Irristesistible Forces, Immovable Objects: Post-industrial Welfare States confront Permanent Austerity." J ournal of European Public Policy, 5(4), 539-60.

Pierson, P. (Ed.) (2001a). The New Politics of the Welfare State. Oxford: Oxford University Press.

Pierson, P. (2001b). "Coping with permanent austerity: welfare state restructuring in affluent democracies." In P. Pierson (Ed.), The New Politics of the Welfare State. Oxford: Oxford University Press.

Scharpf, F.W. (1997). Games real actors play. Actor centered institutionalism in policy research. Boulder: Westview Press.

Scharpf, F.W. (1999). Governing in Europe: Effective and Democratic? Oxford: Oxford University Press.

Scharpf, F.W. and Schmidt, V.A. (Eds.) (2000). Welfare and Work in the Open Economy. 2 Volumes. Oxford: Oxford University Press.

Schmid, G. (2008). Full Employment in Europe: Managing Labour Market Transitions and Risks. Cheltenham Glos: Edward Elgar Publishing.

Taylor-Gooby, P. (Ed.) (2004). New Risks, New Welfare. The Transformation of the European Welfare State. Oxford: Oxford University Press.

Zeitlin, J. (2005). "The Open Method of Coordination in Action: Theoretical Promise, Empirical Realities, Reform Strategy." In J . Zeitlin and P. Pochet (Eds.) (2005), The Open Method of Coordination in Action; The European Employment and Social Inclusion Strategies. Bruxelles: SALTSA, P.I.E.-Peter Lang. 